\title{
Renal Function in Protein-Energy Malnutrition
}

\author{
RAMÓN PANIAGUA, ${ }^{(22)}$ DAVID SANTOS, RODRIGO MUÑOZ, JAVIER LUENGAS. \\ AND SILVESTRE FRENK \\ Departments of Nephrology' and Nuclear Medicine, Hospilal General /R. P., R. M.J: Departments of Nephrology and \\ Nutrition, Hospital de Pediatria (D. S.. J. L.J: and Department of Research in Hospitals. Instituto Mexicano del
} Seguro Social. Centro Médico Nacional /S. F.J. México 7. D.F. Mexico

\begin{abstract}
Summary
So far, most studies on renal function in children with advanced protein-energy malnutrition have shown an impairment of glomerular filtration rate and renal plasma flow, as well as diminished ability to excrete an acid load and a concentrated urine. Investigation of these functions in eight marasmic infants and eight children with $\mathrm{kwashiorkor}$ once they were free of obvious infections and acute electrolyte disturbances has shown a practically normal renal performance.
\end{abstract}

\section{Speculation}

Advanced protein-energy malnutrition does not per se cause renal dysfunction, which rather appears to be due to the usual complications of malnutrition. Various abnormalities in kidney function have been described in chronic, severe, protein-energy malnutrition. Those most frequently found are a diminished glomerular filtration rate and renal plasma flow, an impairment of renal concentrating ability, and a decreased capacity to excrete a maximally acid urine after an ammonium chloride load $(2,8,10)$. However, normal values for various functions $(4,7,9,17)$ have been found in malnutrition not complicated by gastrointestinal or respiratory infections. Present results support the latter notion.

\section{PATIENTS AND METHODS}

Eight infants with nutritional marasmus and an equal number of children with kwashiorkor (20), twelve of them males, as well as five nonmalnourished control subjects were studied. Age of the marasmic infants ranged from 3 to 11 months with an average of $5.9 \pm 2.8$ months; range for kwashiorkor was 17 to 47 months, averaging $25.6 \pm 10.9$ months. Tests were performed 4 to 12 days after hospital admission: at that time. all subjects appeared to be free of complicating diseases as judged by clinical and bacteriological means and were beginning to eat a normal diet.

Glomerular filtration rate as well as effective renal plasma flow. were measured simultaneously by clearance of a single IV load of ${ }^{113 \mathrm{~m}} \mathrm{In}$-DPTA (60 to $70 \mu \mathrm{Ci} / \mathrm{kg}$ body weight) and of $\left.{ }^{9: 25} \mathrm{I}\right] \mathrm{Hippuran}$ $(10 \mu \mathrm{Ci})$, respectively, as described elsewhere $(12,19)$.

Renal acidifying ability was studied after a single PO load of ammonium chloride high enough to reduce plasma $\mathrm{CO}_{2}$ to 15 $\mathrm{mEq} /$ liter. It must be recalled that normal values in Mexico City are lower than at sea level (16). All urine samples voided after the load were collected separately for measurement of $\mathrm{pH}$. titrable acidity, $\mathrm{CO}_{2}$ contents, and ammonium. Hydrogenion excretion was estimated as the sum of titrable acidity plus ammonia minus $\mathrm{CO}$.

For assessment of urine concentrating capacity, the subjects were submitted to fluid restriction by providing a concentrated milk formula during 16 to $18 \mathrm{hr}$; if body weight loss was higher than $5 \%$, the test was interrupted. Urine and blood serum osmolality was measured at the beginning and end of the test.
The randomization test for matched pairs and Mann-Whitney $U$ test were applied to the results (18).

\section{RESULTS}

Values for glomerular filtration rate and effective renal plasma flow, corrected for $1.73 \mathrm{~m}^{2}$, are presented in Tables 1 and 2 . Clearly, individual values fall within normal ranges $(3,21)$.

As shown in Table 3, all values for total hydrogenion excretion are also within normal ranges $(5,6,13)$, although maximal excretion was slower than normal in the malnourished subjects (Fig. 1). Ammonium accounted for 45 to $55 \%$ of the total excreted hydrogenions.

Serum and urine osmolality rose significantly during the water deprivation test (Figs. 2 and 3). Although control subjects achieved higher urine osmolalities, in both types of malnutrition they were well within normal ranges. Only (wo marasmic infants showed a low concentrating capacity (Table 4).

\section{DISCUSSION}

The data herein reported show that in Mexican children with severe protein-energy malnutrition, renal functions are essentially normal.

As seen in hospital wards, this disease is usually complicated by

Table 1. Glomerular filtration rate $\left(\mathrm{ml} / \mathrm{min} / 1.73 \mathrm{~m}^{2}\right)$

\begin{tabular}{lccc}
\hline & Marasmus & Kwashiorkor & Controls \\
\hline & 104.1 & 88.8 & 92.1 \\
& 93.1 & 102.4 & 107.2 \\
& 69.9 & 126.9 & 106.8 \\
& 79.8 & 119.6 & \\
& 81.6 & 104.2 & \\
& 96.1 & 125.0 & \\
Median & 104.6 & 127.3 & \\
Range & 89.5 & 130.0 & 106.8 \\
\hline
\end{tabular}

Table 2. Effective renal plasma flow $\left(\mathrm{ml} / \mathrm{min} / 1.73 \mathrm{~m}^{2}\right)$

\begin{tabular}{lccc}
\hline & Marasmus & Kwashiorkor & Controls \\
\hline & 535.8 & 395.2 & 519.0 \\
591.2 & 510.0 & 411.3 \\
& 384.1 & 304.3 & 432.1 \\
& 403.7 & 510.4 & \\
& 349.8 & 422.9 & \\
& 470.7 & 452.8 & \\
Median & 455.1 & 554.9 & \\
Range & 346.0 & 396.0 & 432.1 \\
\hline
\end{tabular}


respiratory or gastrointestinal infections, aggravated by dehydration and acid-base unbalance, as well as anorexia in most of the patients. Thus, abnormalities in renal functions can be expected. This may actually have been the case in previous reports because

Table 3. Maximum hydrogen ion excretion $\left(E q \mathrm{H}^{+} / \mathrm{min} / 1.73 \mathrm{~m}^{2}\right.$ )

\begin{tabular}{lccc}
\hline & Marasmus & Kwashiorkor & Controls \\
\hline & 69.1 & 191.1 & 90.3 \\
& 76.5 & 228.8 & 105.0 \\
106.1 & 134.1 & 127.5 \\
& 137.6 & 82.2 & 87.4 \\
& 62.4 & 82.8 & 99.2 \\
& 101.6 & 94.3 & \\
Median & 293.6 & 106.0 & \\
Range & 110.5 & & 99.2 \\
\hline
\end{tabular}

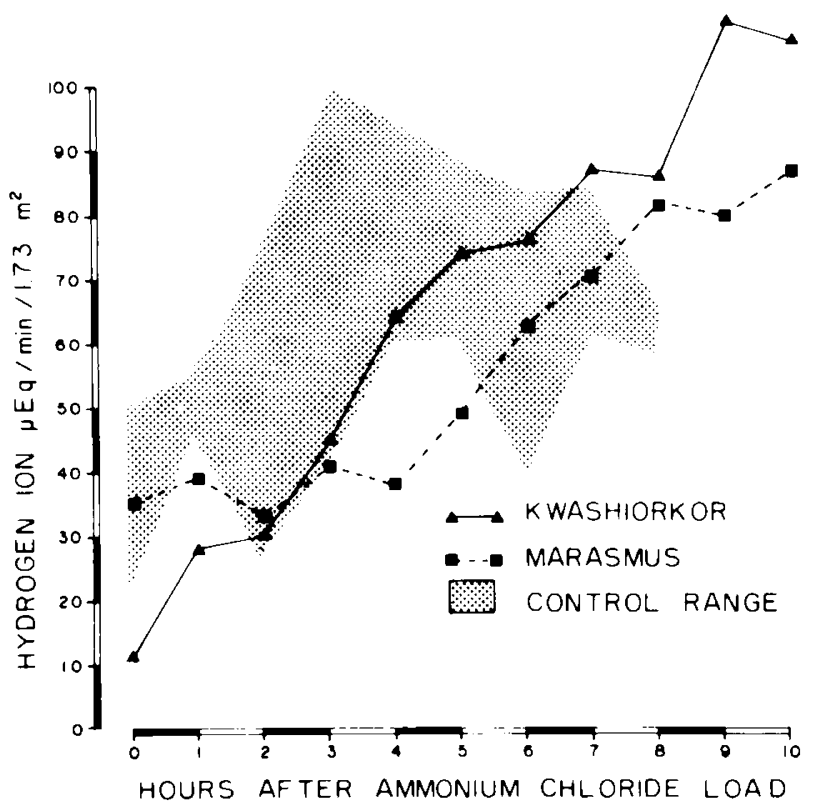

Fig. 1. Hydrogenion excretion (median values) after ammonium chloride load. Shaded area, normal ranges.

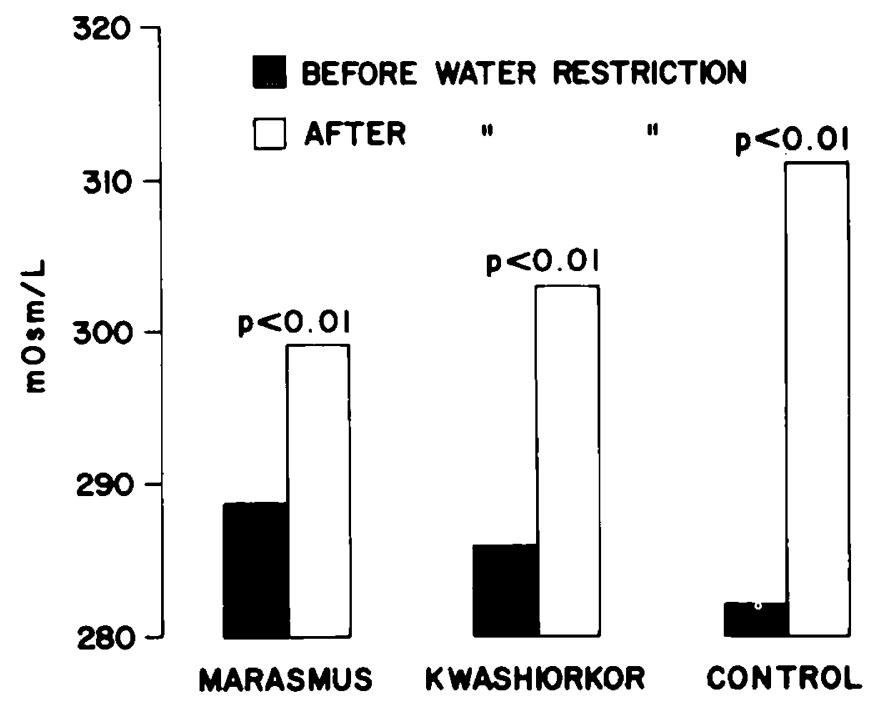

Fig. 2. Serum osmolality during water restriction. Median values for each group.

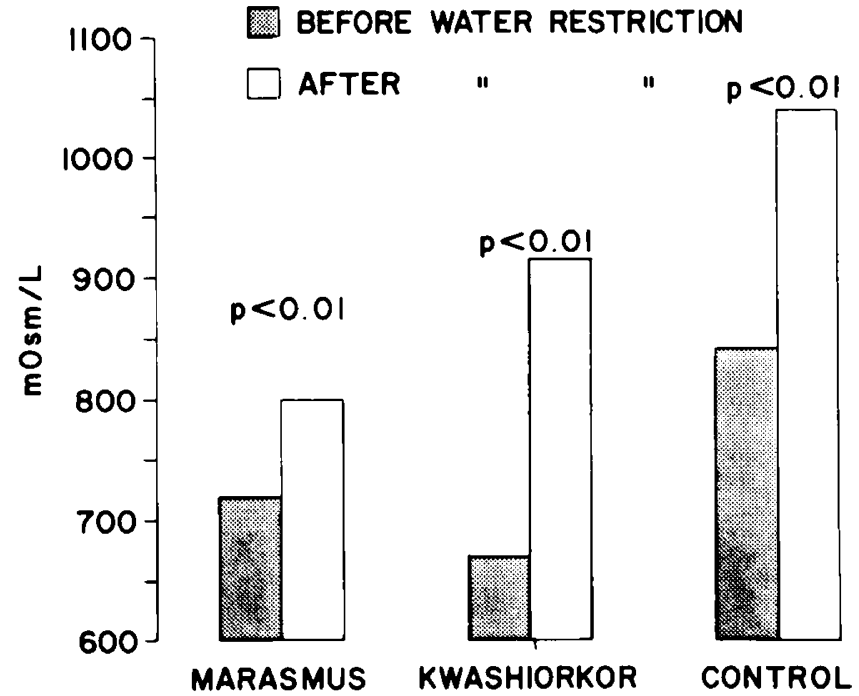

Fig. 3. Urine osmolality during water restriction. Median values for each group.

Table 4. Maximum urine concentrating capacity (mOsm/liter)

\begin{tabular}{lccc}
\hline & Marasmus & Kwashiorkor & Controls \\
\hline & 910 & 952 & 1042 \\
& $558^{1}$ & 1060 & 904 \\
913 & 924 & 1050 \\
& 848 & 849 & 1039 \\
& 740 & 797 & 981 \\
& 1013 & 893 & \\
Median & $550^{1}$ & 979 & \\
Range & 840 & & 1039 \\
& 844 & 924 & 146
\end{tabular}

' Low values.

the clinical status, particularly regarding infectious complications of malnutrition, is not always clearly stated.

Our subjects had completely recovered from any acute electrolyte disorders and were free of clinically obvious infections throughout the study. An improvement of their nutritional status cannot be expected in such a short time with the realimentation procedures used.

In previous reports on deficient renal function in severely malnourished subjects, the findings have been variously explained. Thus, a low cardiac output causing renal hemodynamic changes $(1,2,9)$, depletion of intracellular electrolytes $(11,15)$, as well as a decreased kidney size (14) have all been postulated. Inasmuch as none of these factors is necessarily present in all cases of severe malnutrition $(4,7,9,17)$, their simultaneousness or their coexistence with moderate or severe diarrheal dehydration may have been the cause of the discrepant findings in other series.

\section{REFERENCES AND NOTES}

I. Alleyne, G. A. O.: Cardiac function in severely malnourished Jamaican children Clin. Sci.. 30: 553 (1966).

2. Alleyne, G. A. O.: The effect of severe protein calorie malnutrition on the renal function of Jamaican children. Pediatrics, 39: 400 (1967).

3. Calcagno, P. L., and Rubin. M. I.: Renal extraction of paraaminohippurate in infants and children. J. Clin. Invest., 42: 1632 (1963).

4. Donoso, P., Vial, S., Valdés, G., and Baytelman, E.: Estudio de la función rena en niños desnutridos. Rev. Chil. Pediatr., 41: 17 (1970).

5. Edelman. C. M., Biochis, H., Rodriguez-Soriano, J., and Stark, U.: The renal response of children to acute ammonium chloride acidosis. Pediatr. Res., I: $452(1967)$

6. Edelman. C. M., Rodriguez-Soriano. J.. Gruzkin. A. L., and Acosta. M. I.: Renal bicarbonate reabsorption and hydrogenion secretion in normal infants. J. Clin. Invest., 46: 1309 (1976). 
7. Frenk, S.: Tasa de filtración glomerular en la desnutrición avanzada del niño. Rev. Med. Inst. Mex. Seguro Soc., 13: 141 (1974).

8. Gordillo, G.. Soto, R., Metcoff, J., Lopez-Montaño, E.. and Garcia-Antillón. L. Intracellular composition and homeostatic mechanism in severe infantile malnutrition. III. Renal adjustments. Pediatrics, 20: 303 (1957).

9. Kerpel-Fronius, O., Varga, F.. Kun. K., and Vönöczky. J.: The relationship between circulation and kidney function in infantile dehydration and malnutrition. Acta Med. Acad. Sci. Hung., 5: 27 (1954).

10. Klahr. S., and Alleyne, G. A. O.: Effects of chronic protein-calorie malnutrition on the kidney. Kidney Int., 3: 129 (1973).

11. Metcoff, J., Frenk, S.. Antonowicz, I.. Gordillo. G.. and López-Montaño, E.: Relations of intracellular ions to metabolic sequence in kwashiorkor. Pediatrics. 26: 960 (1960).

12. Möhring, K., Georgi, P., Röhl, L., and Sinn, H.: Simultaneous split measurement of glomerular filtration rate (GFR) and effective renal plasma flow (ERPF) by 1:1 In-DTPA and ${ }^{125}$ I-Orthoiodohippurate infusions clearance following initial double isotope scintigraphy. In K. zum Winkel: Radionuclides in Nephrology. Proceedings of the Third International Symposium. Berlin. April 1974. pp. 309-314 (Georg Thieme Publishers. Stuttgart. 1975).

13. Monnens, L., Schreten. E., and Muster, P.: The renal excretion of hydrogen ion in infants and children. Nephron, 12: 29 (1973).

14. Morrison. E. Y., and Alleyne, G. A. O.: Malnutrition. kidney size and composition. Arch. Latinoam. Nutr., 26: 7 (1976).
15. Nichols, B. L.. Alvarado, M. J., Hazlewood, C. F.. and Viteri. F.: Clinical significance of muscle potassium depletion in protein-calorie malnutrition. J. Pediatr., 80: 319 (1972).

16. Rangel. M. L.. and Bañuelos, J.: Normal values of blood gases in children living at an altitude over 7000 feet. Crit. Care Med.. 4: 311 (1976).

17. Reyes, A., Schenider, R., Winter, A.. Donoso, P., Ferrada, C., Llodra, G., and Mönckeberg, F.: Regulación renal del equilibrio ácido-base en lactantes desnutridos y eutróficos con deshidratación aguda. Rev. Chil. Pediatr., 36: 645 (1968).

18. Siegel, S.: Nonparametric statistics. p. 115 (McGraw-Hill Book Co.. Inc., New York, 1956).

19. Vögeli, B., Riedwyl, H., Donath, A., and Oetliker, O.: Comparison of glomerular filtration rate and effective renal plasma flow determinations obtained by a single injection technique and by means of a standard clearance technique in children. Acta Paediatr. Scand., 60: 528 (1971).

20. Wellcome Trust: Classification of infantile malnutrition. Lancet. 2: 302 (1970).

21. Winberg, $J$.: The 24-hour true endogenous creatinine clearance in infants and children without renal disease. Acta Paediatr.. 48: 443 (1959).

22. Requests for reprints should be addressed to: Dr. Ramon Paniagua. Department of Nephrology, Hospital General, Centro Médico Nacional Ave., Cuauhtémoc 330. Mexico 7. D.F., Mexico.

23. Received for publication March 6, 1979.

24. Accepted for publication February 6, 1980. 